\section{Surety Bond in Infrastructure in Brazil: Transaction Costs and Agency Theory Perspectives}

\author{
Seguro Garantia em Infraestrutura no Brasil: Perspectivas de Custos de \\ Transação e Teoria da Agência
}

\title{
ABSTRACT
}

Context: infrastructure projects assume the use of intensive capital and the participation of several actors, where the institutional environment influences their respective contractual arrangements. A financial instrument for project governance is surety bond (SB), whose purpose is to ensure compliance with the contracted object. However, research involving SB in the context of emerging countries such as Brazil is still incipient. Objective: this study aims to understand the use of SB in Brazil and proposes a conceptual model for analyzing transactions. It contributes to the literature by investigating the relationship between the actors and transactions involved in SB using the transaction costs theory and agency theory perspectives. Methods: this study adopts a qualitative methodology using primary data collected with 10 indepth semi-structured interviews with market professionals with substantial experience in SB. In addition, it uses secondary data based on debate and a specific lecture on the topic involving the reality and the use of SB. Results: the findings indicate that the agency problem and the high transaction costs in Brazil prevent the development of this risk coverage market, giving rise to targeted public policies. Conclusion: the proposed conceptual model reflects the various specific transactions in the use of SB, the underlying phenomena and the validation of propositions related to market failures, and the institutional environment's influence.

Keywords: surety bond; infrastructure projects; Brazil; transaction costs theory; agency theory.

\footnotetext{
* Corresponding Author.

1. Escola Superior de Propaganda e Marketing, Programa de Pós-graduação em Administração, São Paulo, SP, Brazil.

2. Escola Superior de Propaganda e Marketing, Programa de Doutorado e Mestrado em Gestão 2. Escola Superior de Propaganda
Internacional, São Paulo, SP, Brazil.

Cite as: Marques, T. H. M., Ogasavara, M. H., \& Turolla, F. A. (2022). Surety bond in infrastructure in Brazil Transaction costs and agency theory perspectives. Revista de Administração Contemporânea, $26(3)$, e200401. https://doi.org/10.1590/1982-7849rac2022200401.en

Published as Early Access: November 18, 2021.

Assigned to this issue: December 10, 2021
}

\# of invited reviewers until the decision:

\begin{tabular}{|c|c|c|c|c|c|c|c|c|c|}
\hline & 1 & 2 & 3 & 4 & 5 & 6 & 7 & 8 & 9 \\
\hline $1^{\text {st }}$ round & & 9 & & & & & & & \\
\hline $2^{\text {nd }}$ round & & & & & & & & & \\
\hline $3^{\text {rd }}$ round & & & & & & & & & \\
\hline
\end{tabular}

Contexto: projetos de infraestrutura pressupóem o uso de capital intensivo e a participação de diversos atores, onde o ambiente institucional influencia seus respectivos arranjos contratuais. Um instrumento financeiro para a governança é a utilização do seguro garantia (SG) cuja finalidade é garantir o cumprimento do objeto contratado. Entretanto, ainda são incipientes pesquisas que envolvam o uso do SG no contexto de países emergentes como o Brasil. Objetivo: com o objetivo de compreender o uso do SG no Brasil e propor um modelo conceitual de análise das transaçôes, este artigo contribui para a literatura ao investigar a relação entre os atores e transações envolvidos no SG utilizando as perspectivas da teoria de custos de transaçáo da teoria da agência. Métodos: adotou-se metodologia qualitativa com dados primários provenientes de 10 entrevistas em profundidade semiestruturadas junto a profissionais do mercado com notória experiência em SG, e como dados secundários, debate e palestra específicas sobre o tema envolvendo a realidade e o uso do SG. Resultados: os resultados indicam que os problemas de agência e os elevados custos de transaçáo presentes no Brasil impedem o desenvolvimento desse mercado de cobertura de riscos, ensejando políticas públicas direcionadas. Conclusáo: o modelo conceitual proposto traduz as várias transaçôes específicas no uso do SG, os fenômenos subjacentes e a comprovaçáo de proposiçóes relacionadas às falhas de mercado e à influência do ambiente institucional.

Palavras-chave: seguro garantia; projetos de infraestrutura; Brasil; teoria de custos de transação; teoria da agência.

Editors-in-chief: Wesley Mendes-da-Silva (Fundação Getulio Vargas, EAESP, Brazil) Marcelo de Souza Bispo (Universidade Federal da Paraíba, PPGA, Brazil) Guest Editors: João Vinícius de França Carvalho (Universidade de São Paulo, FEA, Brazil) 르 Eduardo Flores (Universidade de São Paulo, FEA, Brazil) Emiliano A. Valdez (University of Connecticut, USA) (1) Reviewers: Luís Eduardo Afonso (Universidade de São Paulo, FEA Brazill Guilherme Fowler de Ávila Monteiro (INSPER Instituto de Ensino e Pesquisa, Brazil) Peer Review Report: The Peer Review Report is available at this external URL. Received: November 30, 2020 ast version received: August 03,2021 Accepted: August 06,202 


\section{INTRODUCTION}

Suretybond (SB) is a type of insurance that underwrites the fulfillment of obligations assumed by the principal party to the obligee party, based on the conditions of the policy issued. In an environment of increasing uncertainty, the demand and search for instruments that guarantee compliance with agreements, such as in large infrastructure projects, has been increasing. The Insight Partners (2020) expects the global SB market to grow from USD 16.07 billion in 2019 to USD 25.18 billion by 2027 , driven by the demand for restoring aging infrastructure in developed countries. The SB market in Brazil had 35 companies in operation and, by September 2020, had a turnover of R\$ 2.3 billion. It represents a relative increase compared to the entire year of 2019, which recorded the amount of R\$ 2.16 billion ( $2.4 \%$ of the world market) generated by 280 thousand policies for large works, contracts, and lawsuits (Brazilian Federal Insurance Office) (Superintendência de Seguros Privados [Susep], 2020a). It is a market that will have a more significant expansion, particularly with the presidential sanction of the new Bidding Law No. 14,133 of 04/01/2021 (Lei n. 14.133, 2021). There is a forecast to increase the value of guarantees for large works and services from $10 \%$ to $30 \%$, which will bring a significant increase in the volume of collected premiums, making this market more vigorous in the coming years (Superintendência de Seguros Privados [Susep], 2020b).

When looking at academic studies, the literature in SB has been approaching the topic from a risk perspective (Beg, 2019; Kim, Cho, \& Ryu, 2019; Surahyo, 2018; Wambach \& Engel, 2011), legal context (Efing \& Desiderio, 2019; Maia, 2013), or in light of a different reality of these markets. For example, in Brazil, authors such as Poletto (2003) and Buranello (2006) analyzed the legal nature of the SB; Poveda (2012) presented the SB as a management tool for mitigating environmental damage in mining; Somavilla and Pereira (2018) studied the use of performance bond in administrative contracts for public works in light of Law No. 8,666/1993; and Terra and Salgado (2020) analyzed the effects produced by default before the term in SB contracts.

However, there is still a misunderstanding about the use of SB in Brazil, in particular from a perspective of the actors' relationship involved, considering the structural and institutional aspects of transactions in infrastructure projects. Moreover, unlike the bilateral relationship between the insured and the insurer in traditional insurance, the SB involves a tripartite relationship (the insured, the policyholder, and the insurer), making the relationship even more complex.
Furthermore, there is a high specificity of assets in infrastructure projects, which require numerous requirements and information with a short deadline for decision-making. As a result, it can favor informational asymmetry between the parties, opportunism, and increased uncertainty. Thus, this study will seek to understand these relationships using the perspectives of transaction cost theory (TCT) and agency theory (TA) to assess the ex-ante and ex-post costs involved in the specific transaction via SB.

Thus, this article intends to contribute to the SB literature in three main points. First, by better understanding the mechanisms that establish the contractual relations in infrastructure projects using the SB. Second, by identifying market incompleteness regarding the effectiveness of the $S G$, which incurs in agency problems, increases transaction costs, and eventually produces barriers to its use in infrastructure projects. Finally, by proposing a conceptual model of the relationships and transactions in the SB in the Brazilian market, which can help in better management and use of this tool in infrastructure projects.

This research used a qualitative approach through content analysis of primary data collected in in-depth interviews with professionals with significant expertise in SB and secondary data based on specific debates and lectures on the subject. The results showed that agency problems and high transaction costs in Brazil prevent further expansion of the SB market, implying the need to elaborate specific public policies.

The article is structured as follows: After the introduction, the second section presents the context of the SB. Subsequently, it shows the literature review on TCT and AT and the respective proposals of the study. In the fourth section, the methodological procedures are detailed, followed by the analysis and discussion of the results section. Finally, the sixth section presents the final considerations, contributions, and implications, as well as limitations and directions for future research in the area.

\section{CONTEXT — SURETY BOND (SB)}

The Insurance Act of 1601 defines insurance as having three objectives: (a) to distribute the losses of a few among many; (b) encourage those who are reticent to take risks before securing compensation; and (c) summoning younger people to be entrepreneurs (Akinradewo, Aghimien, Aigbavboa, \& Onyia, 2020). Thus, one can see the crucial ex-ante incentive instrument for reducing transaction costs whose terms echo even today (Tzirulnik, 2015), and several authors pointed out the positive and relevant character of the insurance market in economic and social dynamics (Hansell, 1996; Pradhan, Arvin, Nair, \& Bennett, 2020). 
Insurers are like institutional investors less willing to oppose company management (Coffee, 1991) and insurance clauses are a way to reduce agency costs (Smith \& Warner, 1979). Insurers gather and manage contributions aimed at guaranteeing economic units exposed to the emergence of needs by homogenizing risks in the community, collectivizing the costs arising from covered claims, and the insurance operation is a collective and inseparable phenomenon (Tzirulnik, 2015). Insurance is universally required to reduce costs related to hiring, control, and conflicts (Krummaker, 2016).

Concerning the $\mathrm{SB}$, the purpose is to guarantee to the insured the provision of substitute execution or payment for the damages that he may suffer due to the principal's contractual default, debtor of the obligation in the guaranteed contract (Beg, 2019; Terra \& Salgado, 2020). Thus, while damage insurance aims to restore the asset to the condition before the claim, in the SB, the objective is broader: to fulfill the obligation assumed by the policyholder through the main contract (Kim, et al., 2019; Surahyo, 2018). Therefore, it means a market failure in the contracting structure also has broader consequences.

The SB's fundamental concept is that default by the principal is avoidable and not a fortuitous event (Schubert, 2000). Thus, the SB can be a rational and effective solution for information asymmetries present in commercial transactions, which are complex and specifically adapted to the problems existing in these relationships (Mann, 1998).
It is a type of insurance with peculiar characteristics, as despite presenting the formal elements typical of the insurance market (policy, claim, and premium), it analyzed the risk in the context of the project itself and with great emphasis on the principal in an environment of financing of the respective project (Brockett, Golden, \& Betak, 2019). In addition, the SB refers to a 'loss avoidance' mechanism designed to pre-qualify individuals based on their credit capabilities and constructive expertise. In contrast, traditional insurance is a 'loss funding' mechanism designed to compensate the insured against unforeseen adverse events (Russel, 2000).

Furthermore, conventional insurance has a statistical actuarial calculation based on the general behavior of the insured portfolio (Hoffmann \& Girolamo, 2017). In contrast, the SB tends to be more similar to credit insurance (Russel, 2000). It implies that the premium is not calculated based on the possibility of an event occurring, but based on a financial credit from the guarantee to the principal, where the underwriting process is more rigorous in that the contractor must provide all confidential information about its finances and business plans (Beg, 2019). Galiza (2015) ponders whether the SB can be considered insurance since some characteristics of this product are not consistent with the standard usually established in traditional insurance. Table 1 compares the typical elements of SB and traditional insurance.

Table 1. Comparative between SB and traditional insurance characteristics.

\begin{tabular}{|c|c|}
\hline Surety bond & Traditional insurance \\
\hline Tripartite transaction & Bilateral transaction \\
\hline No claim is expected & Claim is expected \\
\hline Covers the principal's contractual obligations with the insured & Covers certain events, or all risks (all risks) except those excluded \\
\hline In principle, the three parties benefit from the relationship & The main benefit is the spreading of any losses \\
\hline The principal pays the premium & The insured pays the premium \\
\hline $\begin{array}{l}\text { In principle, the premium is not intended to cover claims payments but } \\
\text { rather technical and financial investigation/monitoring costs, administrative } \\
\text { and commission costs. }\end{array}$ & $\begin{array}{l}\text { The premium intends to cover any payment of claims, administrative costs, } \\
\text { and commission }\end{array}$ \\
\hline $\begin{array}{l}\text { The term is associated with the duration of a specific project and, generally, } \\
\text { policies are renewed annually }\end{array}$ & $\begin{array}{l}\text { The term of the policy has a specific period - in general, one year (except } \\
\text { for engineering risks) }\end{array}$ \\
\hline Policy term lasts even without premium payment & $\begin{array}{l}\text { The term is reduced, canceled, or suspended in case of non-payment of the } \\
\text { premium }\end{array}$ \\
\hline The insurer may require financial guarantees & The insurer does not require financial guarantees \\
\hline Absence of the principle of mutualism & There is the principle of mutualism \\
\hline Right of recourse on the principal, in case of payment of indemnification & $\begin{array}{l}\text { There is no principal figure; the eventual return is on the third party } \\
\text { responsible for the loss }\end{array}$ \\
\hline
\end{tabular}

Note. Based on Russell (2000); Poletto (2003); Buranello (2006); Galiza (2015); Hoffmann and Girolamo (2017) and Brockett, Golden and Betak (2019). 
Mann (1998) clarifies that the use of third parties significantly alters the dynamics of the transaction, as: (a) it establishes a link through legal responsibility, without removing assets from productive use; (b) creates the opportunity for a second check on the principal's credibility; and (c) provides the reliability of the guarantee expected by the insured, based on the insurer's reputation. Thus, the legal relationships that form within the $\mathrm{SB}$ are multiple, with specific characteristics and whose effects resulting from the breach of contracts deserve proper treatment (Efing \& Desiderio, 2019).

In this context, Haddad and Amaral (2011) establish the legal relationship of the $\mathrm{SB}$ and the respective differences concerning bank guarantees. These authors indicate that given the risk of default on the obligation borne by the principal under the main contract, the principal takes out the SB policy to cover such risk with the insurer. In return, the principal signs a counter-guarantee contract (indemnity agreement) to commit to the insurer's reimbursement in case of any payment that the insurer makes in favor of the insured (Poveda, 2012). In turn, the insurer undertakes to pay the indemnity to the insured (obligee) in the claim's event, according to the terms of the policy and based on the rules issued by the regulatory body (Haddad \& Amaral, 2011). In this respect, the guiding elements of the SB contract "are quite peculiar compared to other types of insurance contracts" (Maia, 2013, p. 31, our translation).

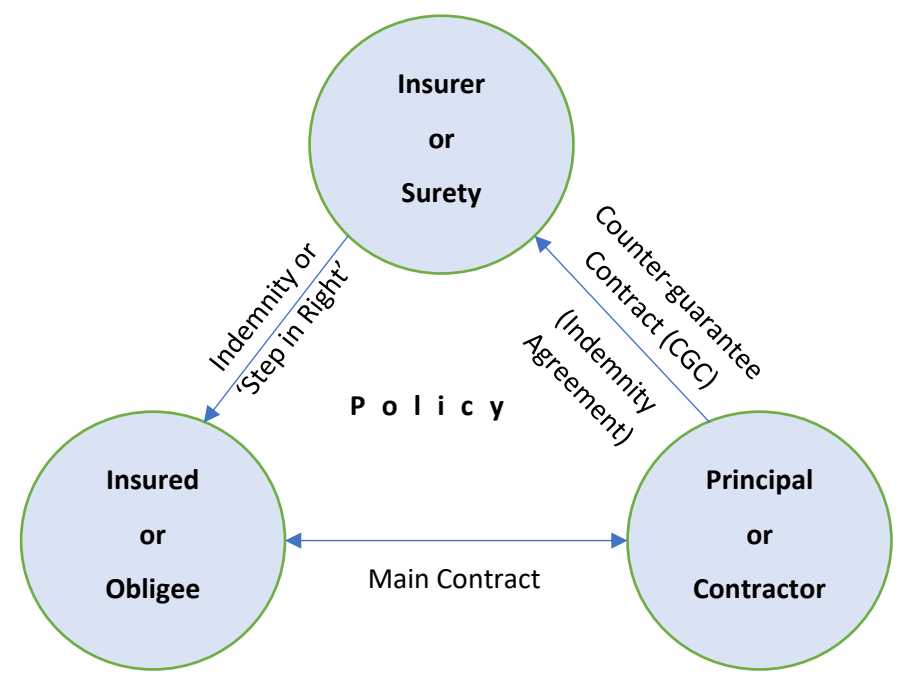

Figure 1. Legal relationship created by the surety bond.

Source: Based on Haddad and Amaral (2011).

In Brazil, it is essential to note that the insurer, in the event of a claim and depending on the contractual conditions, may choose to indemnify the insured for the loss resulting from the default by the policyholder up to the contracted amount limit or exercise the right to finalize the object of the policy (step-in right). Such provision is nonexistent in other types of insurance, as the insurer intervenes in the contract in order to resolve defaults and regularize the activities of the project, preserving the guarantees and contracts of the project (Monteiro, 2016).

\section{LITERATURE REVISION}

\section{Transaction costs theory (TCT)}

Market relations and the regulatory role of institutions establish the basic guidelines for the study and development of TCT (Coase, 1937). The behavioral assumptions of bounded rationality and opportunism guide the contract and governance structures; uncertainty, asset specificity, and frequency are the most relevant attributes to describe transactions (Williamson, 2012). Transaction costs arise from establishing compliance with agreements, where information is expensive and incomplete, while execution is expensive and imperfect (North, 1992). The central essence of TCT is the minimization of transaction costs, with the selection of governance mechanisms as its great stronghold, which is according to the frequency and specificity of assets present in each type of transaction, given that uncertainty is expected and preexisting (Williamson, 2012). More recent publications explore asset specificity and the relevance of uncertainty in governance structures (Schnaider, Ménard, \& Saes, 2018). There are two dimensions of uncertainty: (a) arising from the transaction itself, which originates from institutional voids and increases transaction costs, and (b) economic uncertainty arising from the business 
environment (Smit, Pennings, \& Van Bekkum, 2017). The effects of both are not necessarily the same. While the first, the inexistence of effective mechanisms, can be corrected through some regulatory device, the second obeys a sectorial macroeconomic context, whose analysis must be carried out within a broader context.

Regulation not only plays an important role in the presence of a natural monopoly, but it is a response to the problems created by the spontaneous play of the markets in terms of the production of goods or the provision of services (Dumez \& Jeunemaitre, 2000), assuming a certain balance between the interests of the various social forces involved (Gentot, 1991). According to Williamson (2012) "if the proposed mode is imperfect in similar or different contexts, the alleged advantages of abandoning regulation can be illusory." (Williamson, 2012, p. 299). There is no government intervention, not even regulation, without coalitions attempting to manipulate its outcome where bureaucracy follows its path and can be considered the nexus between conflicting influences (Estache \& Martimort, 1999).

Contracts are incomplete, onerous, and these costs influence the choice of contingencies explicitly contemplated (Hart \& Moore, 2007), with opportunism being one of those responsible for this condition (Williamson, 2012). Previous studies address the relationships of trust between business partners (Baker, 2016; Chiles \& Mcmackin, 1996), with separate dimensions for obtaining it: competence and integrity, the latter being more powerful to reduce transaction costs (Connelly, Crook, Combs, Ketchen, \& Aguinis, 2018). While competence operates within limited rationality, integrity means a reduction of opportunism.

The preference for a transaction via contract grows with the market when there is conviction in support of the legal system, assuming: (a) a propensity to anticipate how the other party will behave within a context of limited rationality, opportunistic incentives, and desire for the mitigation of risks (Chiles \& Mcmackin, 1996); (b) the transfer of supply responsibilities to another party, through pricing, incentives, controls, and penalties (Bhimani, Lopes, \& Aquino, 2016); and (c) low trust and interdependence (Yao, Zhang, \& Brett, 2017).

Williamson (2012) defines (a) ex-ante costs as those incurred in negotiating and formatting agreements, and (b) ex-post costs as those involving the configuration and functioning of the governance structure, including the costs of non-adaptation, binding, and dispute. As the two are interdependent, they must be analyzed simultaneously. Uncertainty influences both ex-ante and ex-post costs (Williamson, 2012), whether due to the possible wrong choice of the partner or due to a failure in the contract design (Marques \& Berg, 2011).
Market failures stem from transaction costs and may even impede the formation of markets. The so-called ArrowDebreu paradigm constitutes a reference in the complete market literature, where a liquid and efficient market covers all risks (Arrow, 1964).

Market failure is characterized when the market cannot allocate resources efficiently from the social point of view (e.g., without state regulation). In large infrastructure projects, there is an informational asymmetry that makes the interested government, when contracting the project with a private partner (contractor, bidder, concessionaire, special purpose company), not to identify a priori, in the bidding of contracting, the type of that partner or the information kept hidden by it, such as its capacity to execute and/or its actual intent to complete the project.

The more complex, unique, and idiosyncratic the product is, the more complex are the contract and the decisions involving capital and governance structures. Products that involve significant contractual risks and uncertainties can lead to opportunistic behavior, generating conflicts between stakeholders and increased transaction costs (Dionne, 2013).

\section{Agency theory (AT) and TCT}

Agency theory (AT) is considered one of the oldest in the management/economics literature. It discusses conflicts of interest in the contractual relationship between principal $^{1}$ and agent, the latter being empowered to manage the business on behalf of the principal, owner, or company's shareholder. It is a multidisciplinary theory used in other fields of knowledge involving social and inter-organizational relationships (Panda \& Leepsa, 2017). Agency costs arise due to (a) separation between ownership and control, (b) different risk preferences, (c) information asymmetry, and (d) moral risks. Jensen and Meckling (1976) bear out that agency costs consist of the sum of the costs of drafting and finalizing contracts, inspecting the agent, the bond, and those associated with the residual loss (Navarro Sanfelix \& Puig, 2018).

Kim and Mahoney (2005) establish a comparison between AT and TCT via a matrix in some aspects. On the one hand, they indicate that the unit of analysis is the contract between principal and agent in AT while it is the transaction in TCT. Also, they show that the main dimension is incentives in AT and types of asset specificity in TCT. But, on the other hand, both theories share the same strategic intent (shareholder view) in addition to some common ground between them in terms of sources of market friction like information asymmetry. Nonetheless, the contractual focus is entirely different: in AT, it is 
ex-ante incentive alignment, and in TCT, choice of ex-post governance mechanisms.

According to Williamson (2002), thecomplementarity between the AT and the TCT approaches is associated with governance issues. While the former concentrates the study on ex-ante phenomena to hiring, the latter focuses on the expost aspects of the realization of the exchange (Silva, 2006). Furthermore, the AT complements TCT because it explains conflict resolution between stakeholders (Dionne, 2013).

Baranoff and Sager (2002), in a study on the life insurance industry, indicate that the two theories predict that more significant conflicts, whether generated by interested parties or by riskier products, lead to a reduction in leverage or an increase in capital to mitigate the uncertainties due to friction. Sun, Garimella, Han, Chang, and Shaw (2020) analyze a blockchain-based decentralized insurance platform provider using these two theoretical lenses. This study concludes, among other things, that the introduction of the blockchain brings (a) two benefits to the peer-topeer relationship: transparency and trust, (b) in addition to reducing ex-ante transaction and agency costs.

\section{Application to surety bond}

\section{Transaction attributes}

The set of transactions under analysis is carried out between actors from different markets in a tripartite relationship (insured-principal-insurer) with several peripheral transactions that support it in a context of high informational asymmetry, low frequency (lower transaction costs), and high asset specificity (see Table 2).

Table 2. Attribute qualifications present in the set of SB transactions in the infrastructure market, according to their intensity in the context.

\begin{tabular}{lll}
\hline Attribute & Intensity & Justification \\
\hline Uncertainty & High & Information asymmetry \\
Frequency & Low, but with a specialized governance structure & Number of insurer-principal interactions \\
Asset specificity & High & A long-term relationship between the parties \\
\hline
\end{tabular}

Note. Elaborated by the authors.

Uncertainty is high, among other reasons, because the insured cannot determine, a priori, the type of principal. In $S B$, the relationship still has additional complexity. It is not just an insured-insurer relationship as in a mutual environment of other products typical of the insurance industry. Therefore, transaction setup increases the uncertainty present in the process. The role of the insurer in this type of transaction is to reduce uncertainty. However, it will naturally be subject to the uncertainty typical of this relationship since, in financial services, the supplier is generally less able to assess the probability of a future loss (Zweifel \& Eisen, 2012).

Regarding frequency, it is an occasional occurrence (annual) linked to projects with unique and occasional characteristics, with a long period of planning, structuring, and execution that invariably consumes years or decades with a specialized governance structure.

Regarding asset specificity, the premium paid in the SB does not serve as a fund for future losses (loss funding) but rather as a loss avoidance. It implies that the insurer takes an active part in the process of preventing the occurrence of a claim and mitigating the effects of its materialization, with regular monitoring of the project's completeness in specific cases and typical clauses such as step-in right. Furthermore, the insurer engages in a close relationship with the principal and the insured. In this sense, there must be a large volume of exchange of specific information for the transaction. Therefore, the transaction has all the requirements for high transaction costs, with the typical consequences pointed out in the literature, such as fundamental transformation (Williamson, 2012) and creeping expropriation (Graham, Johnston, \& Kingsley, 2018).

It is essential to highlight that both the frequency and the assets specificity in transactions are identical regarding infrastructure, regardless of the type of market. Therefore, the difference between a developed country and an emerging market is concentrated on the smaller or larger uncertainty that may arise from some factors detailed in the following topic.

\section{SB transaction conceptual model}

In principle, an informational asymmetry gives rise to contractual risks in complex infrastructure projects. Henceforth, it is a market failure identified as primary informational asymmetry (PIA), often associated with an agency problem. In a market completely within the ArrowDebreu paradigm, SB would mitigate PIA, eliminating the PIA and allowing efficient contracting. 
Based on the literature, we propose a conceptual model (Figure 2) that identifies the incidence of PIA and the manifestation of secondary information asymmetries (SIA, $\mathrm{SIA}_{2}$, and $\mathrm{SIA}_{3}$ ) in the form of adverse selection, in addition to contractual opportunism in the Brazilian market. The traditional insurance literature identifies adverse selection and moral hazard ${ }^{2}$ as ex-ante and ex-post opportunism
(Williamson, 2012). These can be originated by both the insured and the insurer, generating negative externalities such as the costs arising from the loss of confidence in the insurance instrument (Baker $\&$ Logue, 2017). In the present case, there is a manifestation of the PIA and a primary agency problem (PAP), while opportunism and adverse selection appear secondarily.

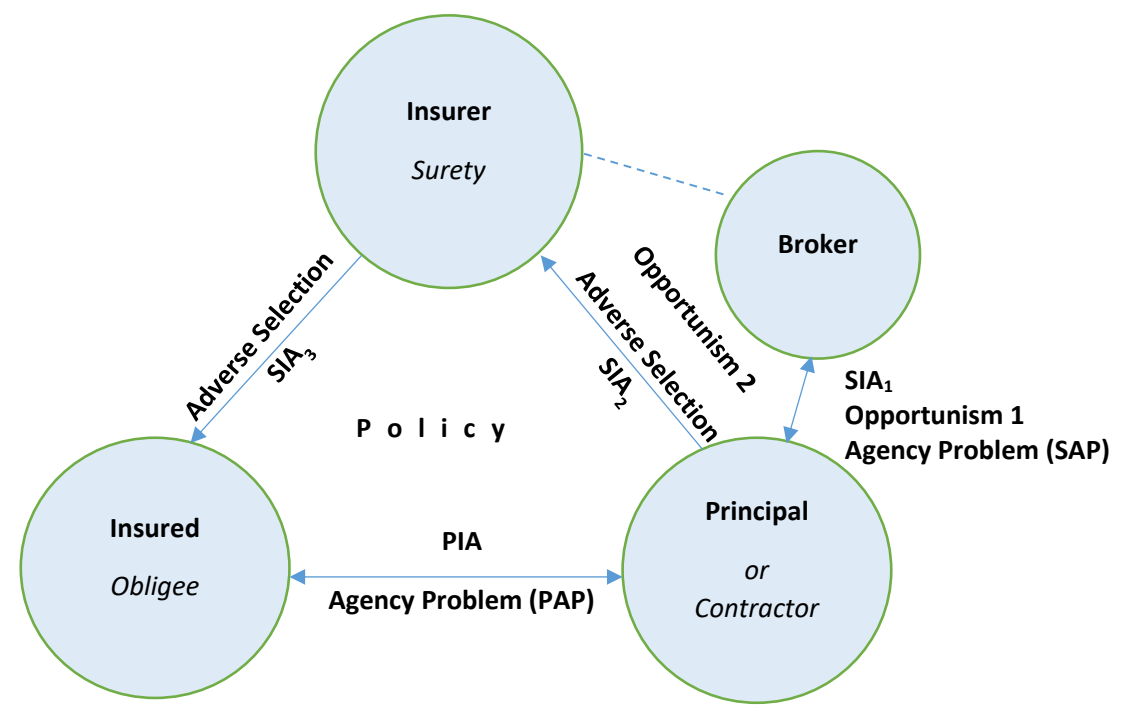

Figure 2. Theoretical model of the SB transaction in Brazil. Source: Elaborated by the authors.

In SB, these phenomena lead to renegotiations of contractual terms, increases in costs and completion time, and loss of efficiency of public contracts (infrastructure), which are transferred and borne by all taxpayers (Giuffrida \& Rovigatti, 2019). However, the mitigation of these opportunistic behaviors can happen due to institutional rules (North, 1992). In other words, good institutional rules can mitigate opportunistic behaviors that compromise the effectiveness of the SB against PIA between principal and insured (obligee), making its application more directed to the Arrow-Debreu paradigm.

Although guarantees respond to potential problems of moral hazard and adverse selection (Giuffrida \& Rovigatti, 2019), when institutions do not provide adequate support against opportunistic behavior, transaction costs are high. In other words, in markets where project completion guarantees are ineffective, the SB no longer has the expected effect of generating a complete market, deviating from the ArrowDebreu paradigm. Ceteris paribus contractual opportunism, the SB mitigates the PIA between the principal and the insured (obligee). When considering opportunism in the contractual environment, this mitigation of the PIA by the
SB is reduced or compromised, leading to the following proposition:

P1: Mitigation of PIA through SB is compromised by contractual opportunism in emerging markets such as Brazil.

The set of transactions in the SB market faces a dissociation between who decides to contract the insurance (insured) and who chooses the insurer and pays the premium amount (principal). In the case of the $\mathrm{SB}$, the contractor's perception of risk tends to be underestimated, which is reflected in the insurance price (premium) and in the coverage contracted (Giuffrida \& Rovigatti, 2019). In this condition, the principal has no incentives to internalize the externalities inflicted on the administration by its choice (Engel, Ganuza, Hauk, \& Wambach, 2006). Thus, ex-ante $\mathrm{AI}$ in the SB market tends to encourage the contracting, by the principal, of lower quality insurers and/or insurance that, in practice, may not provide the risk coverage desired by the insured (Giuffrida \& Rovigatti, 2019). In a broader sense, it can be considered an agency problem (Jensen \& Meckling, 1976). 
The relationship between insured (obligee) and principal within the scope of the SB implies the establishment of some level of trust on the instrument that the principal, as an agent, will contract on behalf of the insured (obligee), establishing an agency relationship. Confidence in the product/service is the belief that it will fulfill its functions as understood by the buyer. Perfect knowledge of the product/ service is strongly associated with buyer confidence (Newell, Wu, Leingpibul, \& Jiang, 2016). Ribeiro, Machado, and Tinoco (2010) identified confirmation of expectations and perceived quality as determinants of quality satisfaction in banking services.

However, unlike the banking service, the insurance market does not offer consumers immediate use of its services. It is just a promise to fulfill the obligation at the time of issuance of the policy in case the covered risk materializes in the future. In other words, it is an obligation whose fulfillment is contingent on a state of nature or a hidden action/information. In this aspect, the perception and satisfaction of quality are strongly and positively related to each other, and the determinants for a positive perception of the service provided are assertiveness, accessibility, corporate image, honesty, competence, and trust (Lakshimi \& Santhi, 2015). Confirmation of expectations and effective observation of the quality of the service provided only occur, in the SB system, when there is a reasonable frequency of claims in which the step-in clause is triggered. Although in emerging markets the number of claims can be significant (Guasch, Laffont, \& Straub, 2008), experience shows that few cases reach the use of the step-in, not generating these requirements. Thus, we propose the following:

P2a: The primary agency problem (PAP) of the $\mathrm{SB}$ is heightened when the insured and the principal do not confirm the expectation of project completion, nor do they perceive the quality of the service provided by the insurer.

In a highly technical decision environment, an element that can interfere in the $\mathrm{AI}$ in the $\mathrm{SB}$ is the participation of the insurance broker, who assumes a privileged informational role in his position of advisor. This agent has the authority to prepare and approve the principal's registration in advance, to negotiate on behalf of these rate and coverage conditions, whose final beneficiary is the insured (Pereira, 2017). The broker can make opportunistic use of the set of information of which disposes to the detriment of the insured's interests (e.g., reducing the price of insurance through limited coverage and/or directing the quote to an insurer that pays a higher commission) without fully meeting the requirements in this type of arrangement (Hau, 2011; Outreville, 2012). This condition can also lead to a secondary agency problem (SAP) when the broker acts in his interest without meeting the expectations of the principal that appointed him (Figure 2). If the broker is competent, SIA tends to decrease. If the broker is ethical, it reduces the chances of having opportunism and/or SAP. However, relational governance structures are more suited to knowledge-based assets, such as in $\mathrm{SB}$, due to the inability to specify processes and results in advance (Hoetker \& Mellewigt, 2009), leading to the following proposition:

P2b: The SB's primary agency problem (PAP) can be mitigated via market adjustments and governance structures.

The difficulty of existing legal and judicial systems endowed with the impartiality that guarantees the fulfillment of agreements can be considered a market failure (North, 1992), as well as the inexistence of consolidated, homogeneous, and presumable jurisprudence (Pinheiro, 2014). Such issues compromise economic development through high transaction costs expressed by legal uncertainty, which affects not only creditors, who may use unfair and opportunistic procedures, but also principals, either by the reduced offer of credit or by the practice of high bank spreads (Yeung, Silva, \& Carvalho, 2014).

\section{Risks in large infrastructure projects}

The main problem in large infrastructure projects is misinformation about benefits (overestimated), as well as costs and risks (underestimated), which leads not only to increased transaction costs but to the emergence of externalities such as reduced benefits and waste (Flyvbjerg, Garbuio, \& Lovallo 2009). Governance structures reduce risks and favor the efficiency of analysis and project feasibility at a minimal cost (Williamson, 2012) through other interested organizations (e.g., banks and insurance companies). These organizations carry out types of due diligence (ex-ante) that produce effects on the fulfillment of obligations (ex-post), reducing the AI as they are efficient in the selection and monitoring of risks (Azevedo, Silva, \& May, 2018).

\section{Legal uncertainty and SB}

Regulatory and judicial institutions are central elements of contract protection (Marques \& Turolla, 2017), and the latter have been gaining more and more prominence within society (Marciano, Melcarne, \& Ramello, 2019). High transaction costs cause distortions in the markets, such as the ex-ante sub-incentive to the offer of risk mitigation instruments that, ultimately, depend on the judicial system for their enforceability, such as the example in the Brazilian SB market pointed out by Hoffmann and Girolamo (2017).

Failures in the judicial system can compromise the effectiveness of corporate law in emerging markets, whether 
due to the lack of robustness of the guarantees required by insurance companies, such as the indemnity agreement, or due to the long-time lapse of a lawsuit (Black \& Kraakman, 1996), which can be used opportunistically by principals who use justice as a way of managing their debts. Therefore:

P3: The legal uncertainty in emerging markets such as Brazil prevents the insurer from exercising the right to finalize the object of the policy in the SB.

Insurance and guarantees are mechanisms to align the underlying incentives to produce a jointly favorable result for both public and private partners. However, this alignment of incentives does not always occur in a reasonable manner (Marques \& Turolla, 2017). It is because high transaction costs prevent obtaining a contract with powerful incentives in the desired direction. It is why transaction costs are essential, preventing the development of adequate contractual incentive systems for infrastructure projects, which ultimately impede the development of infrastructure projects of high economic and social value.

The exaggeration of punitive power and its bureaucratic form within the public sector can characterize the administrative law of fear (ALF), generating inefficiencies in the functioning of the state machine (Campana, 2017; Gondim, Rosário, \& Freire, 2018; Guimarães, 2016). Therefore, Shahab, Clinch, and O'Neill (2018) proposed the development of a category related to 'characteristics of policy' (e.g., simplicity, policy age, policy accuracy, policy approach, public involvement and participation, and policy credibility and consistency) to highlight the importance of choosing and designing a planning policy instrument in terms of transaction costs. With that, we formulated the following proposition:

P4: Bureaucracy and insecurity of regulatory agents in emerging markets such as Brazil are barriers to the exercise of step-in rights in infrastructure projects.

Giuffrida and Rovigatti (2019) found evidence that the SB in the American market helps keep the default rate low, improving the selection of the best contractors. Thus, legal requirements to increase the guaranteed percentages can increase insurers' commitment to insured projects (Guasch, 2004). The effect is to generate greater scale, which tends to increase the solidity of insurers, even under the risks of greater concentration in this market and more outstanding AI, with a more intensive transfer of significant risks to reinsurers.

External or internal factors arising (or not) from institutional limitations (Estache, Serebrisky, \& WrenLewis, 2015), such as an inefficient legal system or the deficient contract structure itself, reduce the propensity of principals to honor their commitments, also increasing the perception of risk by the financial institutions involved and, consequently, transaction costs. Therefore:

P5a: In the absence of a legal requirement on minimum guarantees, low forecasts reduce insurers' commitment in emerging markets such as Brazil.

P5b: High percentages of guarantee generate the more outstanding commitment of insurers through more detailed risk underwriting (ex-ante) and adequate monitoring throughout the contract (ex-post).

\section{METHODOLOGY}

This research implements a qualitative approach based on in-depth interviews, semi-structured with predefined questions according to the literature used. Through a deductive-inductive process (Guest, Namey, \& Mitchell, 2013), 10 professionals who had at least 10 years of experience in SB in Brazil (emerging market) and in the US (mature market) participated in the research. The choice of these countries is because there are no successful cases of step-in right in the public sector in Brazil, in contrast to the American reality, where the SB is widely used by governments, with several successful cases. Three interviews were carried out in the period August-September/2017 and the other seven in August-September $/ 2019^{3}$. We performed face-to-face interviews with seven professionals who work in the Brazilian market and three interviews by telephone with professionals who work in the US. The duration of each interview varied between $30 \mathrm{~min}$ and $1 \mathrm{~h} 10 \mathrm{~min}$, having generated more than 12 hours of recording. We performed a content analysis with the support of the software NVivo.11, aiming at greater rigor, transparency, and organization (Maher, Hadfield, Hutchings, \& Eyto, 2018). During the conduct of the research, we proceed with triangulations using a methodological association matrix, involving the following topics: (a) literature review; (b) proposition; (c) analysis categories; (d) interviews (excerpts); (e) secondary data; and (f) identification of the respective moments of the transaction, and which analysis categories are verified.

For an understanding of the characteristics of the interviewees, we present Table 3 as follows.

In addition, we obtained secondary data from a lecture held via videoconference in $2016(1 \mathrm{~h} 37 \mathrm{~min})$ and a debate held in 2019 (1h45 min), both held in São Paulo, with the participation of several professionals involved in the theme. These professionals discussed the SB issues concerning the American and Brazilian markets (Table 4). 
Table 3. Characteristics of the executives interviewed.

\begin{tabular}{|c|c|c|c|c|c|}
\hline Ident. & Job position & $\Delta \mathrm{t} /$ no. pages & Professional career & Country & Professional experience \\
\hline E1 & Former executive of insurance co. & $0: 37: 00 / 11$ & Engineer & Brazil & 23 years \\
\hline $\mathrm{E} 2$ & Executive of insurance co. & $0: 40: 00 / 15$ & Lawyer & USA & 24 years \\
\hline E3 & Partner of law office & $0: 45: 00 / 23$ & Lawyer & Brazil & 21 years \\
\hline E4 & Partner of law office & $0: 54: 43 / 30$ & Lawyer & Brazil & 20 years \\
\hline E5 & Partner of law office & $0: 45: 26 / 13$ & Lawyer & Brazil & 24 years \\
\hline E6 & Former executive of insurance co. & $1: 15: 00 / 20$ & Lawyer & USA & 40 years \\
\hline E7 & Executive of insurance co. & $0: 49: 24 / 27$ & Lawyer & Brazil & 17 years \\
\hline E8 & Partner of law office & 1:02:00 / 30 & Lawyer & Brazil & 10 years \\
\hline E9 & Executive of insurance co. & $1: 11: 00 / 24$ & Business administrator & USA & 18 years \\
\hline E10 & Executive of brokerage co. & $1: 14: 00 / 24$ & Lawyer & Brazil & 36 years \\
\hline
\end{tabular}

Note. Elaborated by the authors.

Table 4. Secondary data characteristics.

\begin{tabular}{clllll}
\hline Ident. & \multicolumn{1}{c}{ Job position } & $\Delta \mathrm{t} /$ no. pages & Professional career & Country & Professional experience \\
\hline $\mathrm{P}$ & Executive of reinsurance co. & $1: 37: 12 / 25$ & Specialist & USA & 20 years \\
$\mathrm{D}$ & Various & $1: 58: 00 / 38$ & Various & Brazil & N/A \\
\hline
\end{tabular}

Note. Elaborated by the authors.

With the data collected from the interviews and secondary sources (more than 280 transcript pages), we identify differences between these jurisdictions regarding the SB instrument's capacity to function as a risk mitigator in infrastructure projects. The interviews followed a structure based on the elements identified in theory and questions obtained inductively (Figure 2).

\section{ANALYSIS AND DISCUSSION OF RESULTS}

Based on the data obtained in the interviews/ secondary data, we divided the analysis into three groups of aspects: (a) structural, (b) transaction, and (c) institutional.

\section{Structural aspects (trust)}

The structural aspects consist of issues that the market or its actors can address to spread the $\mathrm{SB}$, make its use more common, train professionals who work in it, and reconcile the existing clauses of both the policy and the prominent contract/public notice. It shows the importance of the beneficiary, especially the granting authority, in knowing the product. We highlighted the main themes identified in the interviews/secondary data in the following:
Dissemination and knowledge of the product, professional unpreparedness, adequacy/compatibility of clauses

There is still a misunderstanding about the rules that guide the SB, especially within the granting authority. Based on the literature (Comer, Plank, Reid, \& Pullins, 1999), this reality allows us to infer that there is low confidence in the SB instrument within the emerging market, such as Brazil, due to the lack of knowledge about the mechanisms that guide its use. We verified this situation on the side of the insured/beneficiary and in the market, including brokers and insurance companies. Almost all the interviewees confirm that the American reality is different since it is a very specialized market.

Lack of knowledge of the product in the Brazilian market causes distortions and incompatibilities that are difficult to overcome, such as between public notices and policies. Such a phenomenon, not uncommon, makes the product ineffective, making the environment conducive to the opportunism of all actors. Additionally, the lack of adequate risk allocation in various models of notices aggravates the situation, but insurers accept to issue policies under these conditions, which characterizes opportunism. 
There are so many distortions that it is an instrument for which there is no record of the use of the step-in device within the public sector in Brazil, thus not fulfilling the strategic function expected of it. The effectiveness of the SB is directly related to its connectivity with the main contract, as it is not a standalone product.

The contract (and the public notice that gave rise to it) is only part of this issue. The structuring of an infrastructure project encompasses multidisciplinary teams and involves, among other elements, technical engineering assumptions, judicial and legal aspects, as well as in-depth economic and financial studies. All this work needs to point out a risk matrix with the respective allocation (to the private and/or public entity) more capable of absorbing them and ways to eliminate, mitigate, or transfer them.

The diffusion of SB in the North American market positively impacts the level of specialization of professionals who work there, achieving trust through competence (Connelly et al., 2018). On the contrary, in Brazil, we find an inverse situation with minor diffusion/specialization and, mainly, of the non-confirmation of the social function (stepin) of the SB within the public sector, which means that in part, there is also a great distrust in the market, which is in line with Ribeiro et al. (2010) and Lakshimi and Santhi (2015).

\section{Transaction aspects}

Transaction aspects are associated with the relationships established within the market and the respective failures such as adverse selection, agency problems, and moral hazards. Finally, loss expectation is another element that somehow cuts across all the above and reflects the moment (ex-post) when such phenomena occur.

\section{Ex-ante information asymmetry: adverse selection}

The relationships in the Brazilian SB market have idiosyncrasies that favor negative externalities with high transaction costs involved. There is a situation of market competitiveness in which the providers of the instrument compete on price. However, infrastructure projects presuppose high asset specificity, requiring the same from those who analyze and price the risk.

The principal's posture reflects the dynamics of the bidding when the subject involves the principal's ability to complete the project. The entrepreneur's mentality is to be entirely sure that everything will be solved. The speed and superficiality in the analysis result from the opportunism corroborated by Williamson (2012). In contrast, the
American market is characterized by a long-lasting 20-30 years relationship between principals and insurers.

Although there are differences between the two markets, it is interesting to note that there are many common practices, such as the fact that requests for quotes are made with very little time in advance for their adequate appreciation by the insurer. In addition, the longstanding principal and insurer relationship in the US allows for instant cap approvals. It stems from the insurer's deep knowledge and confidence in the principal (long-term client).

\section{Agency problem}

The search for the lowest price guides the hiring of SB in Brazil since the principal, who pays the premium, does not see the instrument as an essential element in contractual situations in which the guarantee can be used. In fact, the insured is the beneficiary, and, in the principal's eyes, all that remains for him is the onus of bearing the costs of something he has no incentive to acquire, except for the contractual requirement. Added to this is the lack of interest on the part of the public entity during the hiring process. In other words, the principal has a kind of mandate to choose the SB that is in his interest without considering the beneficiary's needs.

On the other hand, according to Debater $\mathrm{D}$, insurance companies "enter this commercial competition many times led by the principal himself, the broker is a victim because he ends up being pressured by the principal to chase the lowest rate. Moreover, when he arrives at the lowest rate, he says: 'Wait a minute, the contract clauses ... I do not like it. Change these clauses here to make it easier for me'. So it goes at the lowest rate and under the most favorable conditions". In turn, Respondent E8 questions whom the broker represents (the insured, the insurer, or himself): "There is some commission negotiation that he also has a certain interest in. So to what extent is there the impartiality of offering all those products or ... value?"

Another important aspect is the fact that the granting authority tries to "transform the performance guarantee into a financial guarantee that does not fulfill the purpose of the insurance," covering "a [daily] moratorium fine. ... The state makes cash with insurance" (Interviewee E4). The positive externalities generated by the completion of infrastructure projects go far beyond the mere payment of fines, whose fate is generally alien to the project itself.

Almost everyone involved accepts the conflict of interest between principal and insured since it does not denature or harm the instrument. AI at SB in Brazil takes place in two different ways: (a) due to lack of knowledge about the product; and (b) due to the adverse selection that is associated with the (main) risk and is the result of 
the potential agency problem that the product initially presents. In any case, the agency problem arises from the low identification in the winning bidder's choice (associated with the PIA) and grows in the secondary adverse selection $\left(\mathrm{SIA}_{1}, \mathrm{SIA}_{2}\right)$ when the high opportunism of the parties involved marks the main insurer symbiosis. It is important to note that the figure of the broker in this process is relevant because if this professional brings together the dimensions of competence and integrity discussed in the literature, there would be a tendency to align the best risk with the best risk mitigation instrument.

In other words, the adverse selection comes from the insurer-principal relationship, which, as observed in the interviews/secondary data, is not that adverse since the opportunism of these two actors marks it. In turn, the adverse selection of the insurer $\left(\mathrm{SIA}_{3}\right)$, arising from the principal-insured relationship, occurs when the guarantee offered does not fully meet the beneficiary's interests, and this actor finds it challenging to observe this situation in advance. There is a connection between the adverse selection and the agency problem, not least because there is a common link: the principal. Nevertheless, the risk that the principal offers the insurer is not necessarily equal to the risk that the insurer offers the insured. The agency problem is prior to the adverse selection due to the timing of the business, given the bidding and contracting process, typical of concession or infrastructure contracts (Yescombe \& Farquharson, 2018).

When we analyze the dynamics of the same relationships in the American market, one can see the influence of formal institutions and informal ones. Therefore, although this article focuses on not addressing socio-cultural aspects, we cannot ignore their power on institutional arrangements.

The step-in right, when exercised effectively, is the crowning achievement of good choices and could be the calling card of surety bond insurers in Brazil with the public sector. Unfortunately, the national insurance market still does not have this evidence, and the perception of the one who pays the guarantee (principal) and of the beneficiary (insured) is that the SB does not offer what it promises. Instead, it makes both actors try to maximize their results, either by paying the lowest price (and the worst service) or by taking advantage of mechanisms existing in the product that compensate or justify the existence of the instrument, leading to the acceptance of $\mathrm{P} 2 \mathrm{a}$. Concerning P2b, we partially support it about market adjustments. However, we could not support the second part of this proposition related to governance structures, requiring further investigation of the issue in future research.

\section{Ex-post information asymmetry: moral hazard}

The insurance literature is about the insured's moral hazard (Reis, 2012), but this risk can also come from the principal in the SB. While in traditional insurance the change in the insured's behavior is not always perceived throughout the policy term, in SB, the insurer can supervise the execution of the contract. This contractual provision can make all the difference in the insured-principal-insurer relationship, reducing the chances of a claim being made or reducing losses if it occurs.

It should be noted that the monitoring of contracts is not done in its entirety. In fact, this is a problem both in the American and in the Brazilian markets. However, there is greater transparency in the US. The principal in Brazil often prefers to omit the information for fear of a rise in the premium. Monitoring has the power to foresee problems, but the reason for its absence is the respective cost. We observe this reality in both markets, but in Brazil, the competition of rates (if the premium is low, there is no room for effective monitoring) aggravates it.

Contractual defaults are intrinsic to monitoring that, in Brazil, come mainly from the government itself. However, the more active participation in the contractual relationship by insurers entails transaction costs and, due to opportunism and low remuneration, they prefer to run the risk of not carrying out the monitoring.

This situation tends to change, as mentioned above, due to Law No. 14,133/2021 in which it is foreseen that "the insurer shall sign the contract, including the amendments, as the consenting intervening party" (Lei n. 14.133, 2021).

The American market, perhaps, can afford not to carry out the monitoring correctly, since it has in its favor a low AI combined with the solidity of the relations between principals and sureties. However, the moral hazard present in the Brazilian SB market can be associated with all actors, including the insurer, as it does not perform the service it could provide. As this is available to the insurer, companies generally choose not to monitor, even in an environment of high $\mathrm{AI}$ and low trust.

Although it results from the strategy pursued by each insurer, our findings reveal that this phenomenon occurs in advance at the time of risk acceptance. It shows an adverse selection of the insurer or an adverse selection 'inversely.' However, we cannot affirm that this is a random adverse selection, given that the principal seeks to obtain the guarantee that offers the lowest cost, which presupposes the worst service and/or the most restrictive coverage. This situation cannot be generalized, but it is one of the research findings. Thus, for this guarantee to mitigate the risks desired 
by the beneficiary as presented in the literature (Giuffrida $\&$ Rovigatti, 2019), there must be a reduction in SIA through contractual provisions within the bidding process.

\section{Claim adjustment}

Even though the process for adjusting and settling a surety claim is complex, in the US, it is very fluid and cannot exceed more than 30 days. However, the dynamics of the parties' relationship within the American legislation makes the claim ratio to be at most $20 \%$.

The insurer has six options to settle the claim "already predefined in the clauses" (Debater D): "[1] it can assume and complete the project, the famous 'assume and complete"; "[2] bid for a new contractor"; "[3] finance the original contractor to complete the project"; "[4] indemnify the insured"; "[5] transfer ... the bond"; and "[6] deny the claim." The most common forms of project completion are: "Or ... the insurer somehow assumes [the work] ... or outsources or brings in someone from outside." Nevertheless, a fact that makes all the difference in the American market is that "it is not an option for the insurer to pay [indemnity]" as in Brazil.

The time and bureaucracy in many of the surety claim processes in the Brazilian market, especially those involving public bodies, seem to be the elements that clash the most. However, again, it reflects a little of Brazilian law itself and the reality of informal institutions.

There is also, in Brazil, an aggravating factor with the autonomy of the granting authority, in the sense of "making agreements feasible in the administrative sphere, although there is already mediation and arbitration" (Interviewee E5). However, these conflict resolution devices still need to be assimilated by the state. In the US, the problem is not time: "Arbitration is more uncertain than justice" because, in general, "SB has a strong legal position" and "arbitrators do not need to follow what the courts have defined as a rule" (Interviewee E6).

Many problems could be solved quickly without the lack of underwriting or teratological contracts that do not dialogue with each other. However, due to the specificity of the projects, others can make the step-in process extremely complex to occur, demanding, in turn, the sophistication of the professionals who work in claims adjustment. In turn, it is the most critical step within any insurance. In this process, it is typical the emergence of several topics for discussion - issues not observed in due time, unresolved problems, aspects that go beyond the letters of the contract, entry of new actors (not involved in the original relationship), mismatch of information - many variables and very few equations for the solution. In addition, there is the animus of parties litigation, in a relationship that, not rare, is already destroyed for different reasons.

The complexity of projects and contracts covered in the SB can be high, especially in infrastructure, regardless of the country. Nevertheless, the American SB market presents a quality in providing services that allow it to: (a) quickly resolve claims even without adequate monitoring; (b) offer a more comprehensive range of predefined settlement options, where the beneficiary is sovereign as to the final choice. However, the public authorities in the US have more autonomy and commitment in resolving claims and a greater understanding of the SB.

In summary: (a) in Brazil, conflict resolution can last for years (if not more than a decade, through judicialization); (b) the state for a long time was and still is primarily inoperative, bureaucratized, which gives rise to opportunism by insurers and also by principals; (c) the legal framework does not encourage the speed of proceedings; (d) the ALF is always present in public bodies; (e) the state is not yet prepared to resolve conflicts through mediation or arbitration, that is, judicialization is the rule; (f) in general, the granting authority does not know the instrument of the $\mathrm{SB}$.

Although many of the Brazilian insurance companies that operate with $\mathrm{SB}$ are multinational enterprises (with expertise in the American market), they still present a level of service far below those of the North American ones, without incorporating the best practices in the field. It occurs both in risk acceptance and pricing, as well as in monitoring and loss. Law No. 14,133/2021 (Lei n. 14.133, 2021), which will be discussed further in the next topic, brings some advances that will require insurers to play a leading role that few can play today. Therefore, they may adopt procedures that compensate for the 'gravity' of the public beneficiary, where everything gets stuck, everything takes a long time. One of the options for this (within insurers' limits) may be the effective monitoring of projects (at least the more complex ones) so that the solution is more immediate in the event of a claim.

In light of the theory, the fluidity of processes through knowledge of the rules among all actors, the legal framework that privileges contracts (common law), the agility in procedures, the proactivity and autonomy of public managers, and the reduction of the bureaucracy of administrative services reduce transaction costs. However, the Brazilian reality makes transaction costs much higher, especially in the presence of opportunism.

The work of the court of auditors could contribute to greater consistency throughout the process. However, they establish the ALF, causing the opposite effect (Campana, 2017; Gondim et al., 2018). This phenomenon causes, in 
critical cases, the public manager to choose to transfer his decision-making power to the judiciary. In fact, the Brazilian judiciary has been a shield of protection for both the public employee (insured/beneficiary) and the debtor (principal) - the former is exempt from exposing his personal records for misconducts judged by the courts of auditors and the another manages its debts, rolling them over in a time of inefficiency of justice and the resources provided for by law.

Step-in is the goal sought by all society. Moreover, the only viable way to do this, within the limits of the private sector, is through a quality service provision: successful claim adjusting with transparency and fluidity of information. It is useless to have adjusters and qualified experts if the problem is at the origin of hiring. Much of the solution focuses on legal certainty, which will be discussed below. However, independent mediation and external audit, preceded by adequate monitoring of projects, are the forms of governance that will allow insurers to achieve a reputational level in the SB comparable to other companies in different branches of the insurance market. Thus, the $\mathrm{P} 4$ proposition is supported.

\section{Institutional aspects}

The institutional aspects mention the legislation, regulation, and legal uncertainty that interfere directly in the transaction aspects and indirectly in the structural aspects.

Law

The literature shows evidence that coverage percentages are positively related to insurers' commitment and, therefore, to the effectiveness of the SB (Guasch, 2004; Giuffrida \& Rovigatti, 2019). In Brazil, Law No. 14,133/2021 (Lei n. 14.133, 2021), by proposing to increase the coverage percentage to $30 \%$, presents some aspects that deserve more detailed analysis. A counterintuitive aspect of this proposal is the increase in the aggregate volume of transaction costs associated with the SB contracts themselves. Thus, proposition P5 addresses a current issue in the Brazilian insurance market when dealing with the legal requirement to increase the percentage of coverage.

According to all professionals who participated in the survey, there is unanimity in the market that the percentages provided for in the current order (5\%-10\%) are insufficient for the completion of any project. It means that the performance bond can only meet the fines imposed by the public administration. However, in the US, guarantees start at $100 \%$, making the project's completion more feasible.

Another reason why the step-in is not yet feasible in Brazil, especially in the public sector, is that the insurer assumes a series of risks (e.g., labor, social security, environmental, among others); even with contractual clauses that seek to shield this responsibility, Brazilian legislation does not provide the due support. In a comparison between legislations, Speaker P indicates that "Brazilian legislation is not specific [even] on how an insurer can intervene in the contracts it is guaranteeing" and adds: "[In the US] the legislation has a well-established claim process," with no automatic transfer of these risks to the insurer.

There is much expectation in the Brazilian insurance market due to the new bidding law (Lei n. 14.133, 2021) that can improve the institutional environment, offering more strength to the SB instrument. However, essential issues are no longer covered: (a) whether insurers will (or will not) have the freedom to contract/replace the principal; (b) whether there will be (or not) a new bid and, if so, what type of bid will be made (technique and price, or just price); (c) what will be the hierarchy between the parties: public or private law?

On the other hand, the new legal framework has controversial aspects, such as a penalty for the insurer who does not opt for the step-in. In this case, it causes a fine of $100 \%$ of the insured amount. Therefore, it can be considered contrary to the indemnity principle, leading to lengthy discussions and legal uncertainty. However, if the SB has particularities compared to other insurance types, this instrument's indemnity principle considers the common interest of the parties involved, which is the conclusion of a project (performance bond).

Payment of the entire policy amount is unrelated to the actual loss. However, this is an option for the insurer if it decides not to perform the step-in. This type of arrangement can be considered 'liquidated damages' arising from 'common law' or pre-agreed damages with the nature of a fine in the Brazilian system. The money's destination can be used for purposes other than the guaranteed project. In other words, no seal is indicating that the indemnity will have to be applied to the insured enterprise. It is important to emphasize that there is no bad faith on the part of the granting authority. On the contrary, it is a contractual incentive to complete the project that the insurer agrees to when issuing the policy. With this, we support propositions $\mathrm{P} 5 \mathrm{a}$ and $\mathrm{P} 5 \mathrm{~b}$.

\section{Regulation}

The SB has standard clauses governed by Circular Susep No. 477/2013 ${ }^{4}$ (Circular, n. 477, de 30 de Setembro, 2013), in which the contractual provisions divide into general conditions, special conditions, and particular conditions. Insurers are free to change only this last part, as long as it is not restrictive for the insured, which "leaves the product very rigid" and, sometimes, "it does not serve to 
guarantee that specific risk," explains E8 - in some policies "everything is defined via a particular condition."

Another aspect contributing to the market's low dynamics is the delay in approving a new product with Susep. Although the objective of the autarchy is to reduce AI in the market, by standardizing clauses, there is no incentive for innovation (whether genuine or imported). There is still a certain comfort on the part of insurers regarding the role of Susep. State paternalism generates opportunism and legal uncertainty for the markets, in addition to the apparent lack of innovation.

It is important to note that the low flexibility to the policy's contractual conditions generates opportunism for the principal. However, there is no need for hypo-sufficiency in this type of insurance and even less within the infrastructure market. Another point refers to the misunderstanding of the instrument, which is also associated with the format given to the product by Susep, whose objective should be to oversee the market and not 'stuck' products, as highlighted by respondents E7, E8, E10, and as Polido (2015) alerts, with reasons to identify signs of over-regulation.

Susep has been discussing the obligation to express the commission paid to the broker in the policies. Based on this data, it will be possible to identify "if there is any bias" on the part of the broker or even if "it is not just consideration [but], in fact, the commission", according to E8. This situation is favorable in obtaining transparency in the hiring process, producing positive externalities, the main objective of all regulations.

\section{Legal uncertainty}

The solution of claims is not always made through administrative channels. However, it happens that the Brazilian judiciary, in general, knows little about insurance and even less about $\mathrm{SB}$, with no jurisprudence on the matter. This lack of predictability regarding the content and application of rules impacts the development of economic activity and increases transaction costs (Pinheiro, 2014).

A disagreement or doubt about the terms of the contract can lead to endless court battles. It is a different reality from that commented by all interviewees who work in the American market, where most of the conflicts are resolved consensually without the action of justice, even because the cost of litigation is considerable. Another point mentioned by E6 (i.e., arbitration) refers to the intense legal position of the instrument in the US, which also explains the refrain of Americans from fighting in court.

The range of possibilities (or uncertainties) in the American judiciary seems relevant, but they start from contractual provisions that its actors within the SB fully know. Uncertainty occurs when the decision is passed on to a 'stranger' in the relationship without consensus between parties. In Brazil, the discussions are much broader because the market is not yet mature or because the legal framework does not offer the necessary freedom for individuals to transact as they see fit. Nevertheless, we cannot forget another component: opportunism (or even bad faith). On this topic, Debater D expands the discussion: "The legal uncertainty is in all aspects ... Would it give more freedom to negotiate a claim? And wouldn't it be good to move the work forward? Without his CPF being attached?"

In Brazil, in addition to not having a clear and objective definition of certain concepts, litigation becomes even more confusing, according to E4: "You have a state court talking about insurance and arbitration ... in a contract of ... a concession [or vice versa]" - the two processes run parallel and often the insurer is in the legal process. However, the insurer is not a party to the arbitration. Furthermore, E5 explains, "sometimes the insurance company does not participate in arbitrations ... [which] have a confidentiality clause; in short, a third party cannot know what is happening there." Thus, E4 concludes: "It makes no sense to have an insurance discussion in one court and a discussion of the guaranteed obligation in another."

All this complex controversy migrates to an inefficient judiciary, as E3 indicated: "An infrastructure project cannot wait $10-15$ years to be completed, due to a loophole for legal discussion"; and E3 concludes: "In Brazil, there is no guarantee instrument that works in its fullness."

E1 highlights: "It is necessary to make credit recovery instruments effective ... Currently, counter-guarantee contracts are not considered executive titles ... causing the final judgment to take more than a decade to be passed. In the meantime, the main thing may even cease to exist." In turn, Interviewee E4 says: "The poor insurer keeps that CCG ... that has no liquidity, no feasibility, [and that] is why it cannot reimburse itself." Debater D explains that "here the guarantee systems are super stuck because they need the execution of the good, the judicial sale, and that kind of thing. There [outside] it works better." A critical piece of information mentioned by E2 is related to "indemnity agreements" (our CCGs), which "have force in the American courts, and a final decision can be obtained in one-two years at the most."

Legal uncertainty in Brazil is broad and deep, and every society pays a high cost for it. The SB's social purpose (step-in) does not escape its harmful effect. All aspects heavily discussed in the interviews/secondary data above corroborate the literature (Esplugues \& Marquis, 2015; Pinheiro, 2014). Legal uncertainty within the scope of the $\mathrm{SB}$ in Brazil ranges from a simple word to more complex issues such as expiration and contractual rebalancing, 
including the lack of jurisprudence. The contractual dispute resolution provisions themselves clash with the traditional litigation procedure. Added to this are the eternity of the processes, the (counter) guarantee instrument with a more psychological than practical effect, and the absence of distinctions among surety creditors in credit recovery. For all these pieces of evidence, and comparatively in relation to the legal 'uncertainty' in the American market, we concluded that there is an abysmal difference between the two countries. Therefore, the $\mathrm{P} 4$ proposition is supported.

\section{FINAL CONSIDERATIONS}

This article sheds light on typical issues in the institutional environment of emerging countries, such as Brazil, regarding the effective development of large infrastructure projects. The incompleteness, agency problems, and transaction costs present in the mitigation of infrastructure project risks in Brazil, through the SB instrument, were duly identified, understood, and qualitatively evaluated through in-depth interviews.

Some issues are associated with the idiosyncrasies found in the use of SB in Brazil, such as opportunism, a transactional and contractual culture, and the mentality of the actors involved, which can take decades to change. However, the root of the problem may be associated with the existing legal framework and the slow adaptation of the insurance market to it, conditioned in part by the limitations imposed by the regulatory body.

The lesser commitment of insurers and the low level of information exchange within the market lead to less efficient underwriting and monitoring, further contributing to widespread professional unpreparedness (even within the insurance market), which feeds low diffusion and ignorance of the SB, which favor the creation of notices and products that are inconsistent with each other. Thus, it can be said that in this theoretical model, there is a vicious cycle.

The legal framework ended up institutionalizing a market of ineffective guarantees in the public sector, making the SB's social function unfeasible. This institutionalization can be seen in the atmosphere of mistrust that has been established among its actors, where AI and opportunism end up being rhetoric and causes for uncertainty and the most diverse negative externalities. In this aspect, the judiciary does not help because of its slowness, lack of jurisprudence consolidation in the higher courts, or lack of understanding of the basic principles and conditions that guide the instrument.
The present study offers three main academic contributions to the literature. First, it expands knowledge about markets and risk coverage of large projects in an emerging market such as Brazil. The second contribution refers to reduce existing gaps in understanding the use of $\mathrm{SB}$ as a risk mitigation instrument. Third, we propose a conceptual model of the SB's relationships and transactions in an emerging market like Brazil. Taking up the conceptual model and analyzing it in light of the propositions made and the results obtained, we conclude that it reflects the reality of the phenomena identified in emerging markets such as Brazil. It is crucial to indicate that the object of analysis is related to the specific transactions underlying the SB (i.e., transaction aspects), and the structural aspects emerged inductively during the research. Thus, propositions P1, $\mathrm{P} 2 \mathrm{a}, \mathrm{P} 2 \mathrm{~b}$, and P4 refer to the transaction itself. On the other hand, propositions $\mathrm{P} 3, \mathrm{P} 5 \mathrm{a}$, and $\mathrm{P} 5 \mathrm{~b}$ associate with institutional aspects. For a better understanding, we show in Figure 3 the conceptual model with adjustments based on the findings and the scope of the groupings and their respective propositions.

We pointed out two significant managerial implications. First is the choice of governance instruments such as specialized advice (advisor) or training of policyholders/beneficiaries and improvement of standard of procedures, partially supported in this research. The second implication is about the development of more effective contractual solutions given the phenomena highlighted here. With the breakdown of each of the relevant primary and secondary effects, it is possible to think about the development of contractual instruments (from the perspective of governments, regulators, insurance companies, financers, and the market in general) in a more directed way to the mitigation of market failures underlying each of these effects. Therefore, it establishes a more effective conceptual model for the development of risk mitigation contracts that can truly contribute to the development of the various economic and social infrastructure sectors, with significant social and economic implications.

Nevertheless, this research has its limitation. Our sample comprises professionals with great expertise and knowledge on SB insertion in the insurance market. Future studies could expand the sample with representatives of the granting authority, development banks, Susep, and principals from different infrastructure sectors. It is also noted that there is no database on the SB in Brazil that allows for mixed research (qualitative and quantitative) or even quantitative research. 


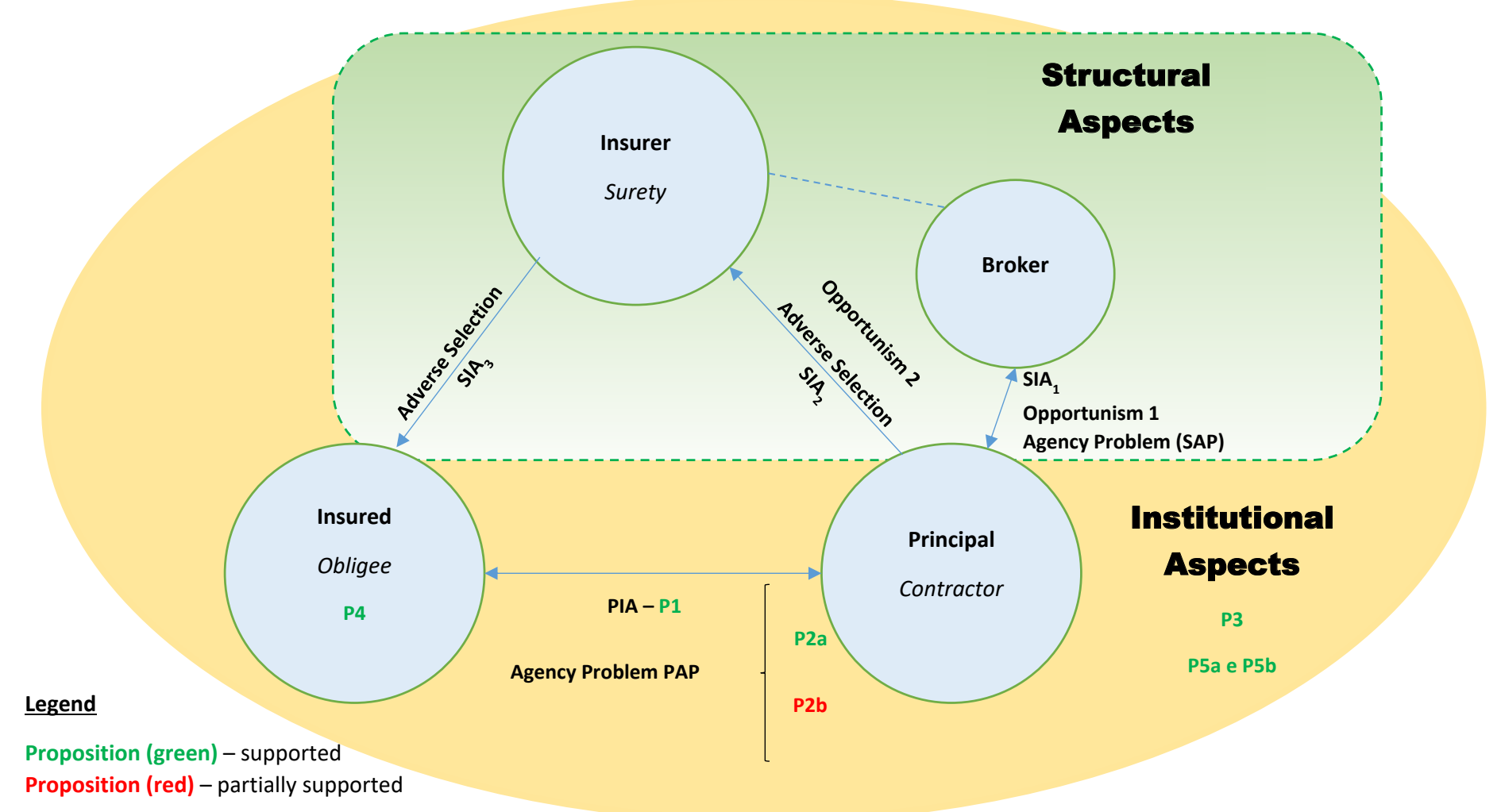

Figure 3. Final conceptual model.

Source: Elaborated by the authors.

On a qualitative basis, this study raised the structure of the phenomena underlying infrastructure contracts and the use of SB. For future research, there is a need to move toward the quantification of the phenomenon. For a safer assessment of the effectiveness of the SB instrument, this study proposes a conceptual model with analytical indications for the breakdown of the phenomenon. There are two types of effects. First, the primary effects, which refer to the fundamental issues of information asymmetry and agency problems inherent in transactions in large infrastructure projects, which could be quantified in terms of (ai) avoided transactions, (b) additional cost of transactions carried out in terms of rates of return required by the additional risk and other costs, and (c) externalities associated with infrastructure projects. Therefore, to make this idea tangible, intuitively, these direct effects are the negative consequences of market failures without proper mitigation by instruments such as the SB.

Second, it is crucial to advance in quantifying secondary effects resulting from the very use of the $\mathrm{SB}$ instrument as a mitigator of primary failures. These are related to issues of (a) contractual opportunism, (b) additional informational asymmetries, and (c) agency problems, plus (d) similar phenomena arising in the peculiar relationship between broker and principal of SB. These failures give rise to new risks that raise the rate of return of projects (designed to reduce them), the unwanted realization of teratological contracts, and the underperformance of infrastructure projects itself, with the consequent positive externalities that are avoided. Thus, there is an avenue of opportunity for the future research agenda, with high social value, resulting from this research, involving quantifying the elements exposed here.

\section{NOTES}

1. It is important to note here the inversion of the logic and nomenclature presented in the agency theory when we analyze only the contract signed between the government and the private partner (for example), since the main term is used to identify the contracting party in the relationship.

2. Le Roy and Singell (1987), for example, interpreted the distinction made in 1921 by Frank Knight between risk and uncertainty as situations in which insurance markets: (a) can operate without problems; and (b) would collapse due to moral hazard and adverse selection. 
3. The interviews were carried out at different periods due to the phases of development of the research project. However, the time difference did not have any impact on the perception of respondents, since the legal and regulatory frameworks, specific to this area, remained the same.

4. On 09/26/2018, Susep issued Circular No. 577, which included in Annex I of Susep Circular No. 477 (of

\section{REFERENCES}

Akinradewo, O., Aghimien, D., Aigbavboa, C., \& Onyia, M. (2020). Factors influencing the adoption of insurance as a risk treatment tool by contractors in the construction industry. International Journal of Construction Management. https://doi.org/10.1080/15623599.2020.1797986

Arrow, K. J. (1964). Control in large organizations. Management Science, 10(3), 397-408. Retrieved from https://doi.org/10.1287/mnsc. 10.3 .397

Azevedo, E. M. L., da Silva, A. C. O., \& May, M. R. (2018). Análise do modelo de negócio das ventures builders. Revista de Empreendedorismo e Gestão de Pequenas Empresas, 7(1), 104-129. https://doi.org/10.14211/regepe.v7i1.498

Baker, N.B. (2016). Transaction costs in public-private partnerships: The weight of institutional quality in developing countries revisited. Public Performance \& Management Review, 40(2), 431-455. https://doi.org/10.1080/15309576.2016.1244092

Baker, T., \& Logue, K.D. (2017). Insurance law and policy: Cases and materials. New York, NY: Wolters Kluwer.

Baranoff, E. G., \& Sager, T. W. (2002). The relations among asset risk, product risk, and capital in the life insurance industry. Journal of Banking \& Finance, 26(6), 1181-1197. https://doi.org/10.1016/S0378-4266(01)00166-2

Beg, M. A. (2019). Default insurance and surety bonds: The difference and how they operate. International Journal of Law, 5(1), 30-32.

Bhimani, A., Lopes, A. B., \& Aquino, A. C. B. D. (2016). Measurement costs and control in outsourcing relationships. International Journal of Managerial and Financial Accounting, 8(3-4), 296-318. https://doi.org/10.1504/IJMFA.2016.10002756

Black, B., \& Kraakman, R. (1996). A self-enforcing model of corporate law. Harvard Law Review, 109(8), 1911-1982. https://doi.org/10.2307/1342080

Brockett, P, Golden, L., \& Betak, J. (2019). Different market methods for transferring financial risks in construction. In N. Khatleli (Ed.), Risk management in construction projects. London, UK: IntechOpen.
09/30/2013) the chapter IV - "Special conditions for additional coverage" — branch 0775. However, the changes introduced by Circular No. 577 are restricted to employment contracts with exclusive dedication of labor, which have no relevance in the context of infrastructure projects covered by the surety bond. It is widely recognized in the literature that infrastructure assets are capital intensive and that the weight of labor in the underlying production function is of little materiality.

Buranello, R. (2006). Do contrato de seguro: O seguro garantia de obrigaçôes contratuais. São Paulo, SP: Quartier Latin.

Campana, P. (2017). A cultura do medo na administração pública e a ineficiência gerada pelo atual sistema de controle. Revista de Direito, 9(1),189-216. Retrieved from https://periodicos. ufv.br/revistadir/article/view/252703892017090107

Chiles, T. H., \& McMackin, J. F. (1996). Integrating variable risk prefernces, trust, and transaction cost economics. Academy of Management Review, 21(1), 73-99. https://doi.org/10.2307/258630

Circular no 477, de 30 de setembro de 2013. (2013). Dispóe sobre o Seguro Garantia, divulga Condiçóes Padronizadas e dá outras providências. Rio de Janeiro, RJ. Retrieved from https://www.in.gov.br/en/web/dou/-/circular-n-477-de30-de-setembro-de-2013-31065813

Coase, R.H.(1937). Thenatureofthefirm.Economica, 4(16),386-405. https://doi.org/10.1111/j.1468-0335.1937.tb00002.x

Coffee, J. C. (1991). Liquidity versus control: The institutional investor as corporate monitor. Columbia Law Review, 91(6), 1277-1368. https://doi.org/10.2307/1123064

Comer, J. M., Plank, R. E., Reid, D. A., \& Pullins, E. B. (1999). Methods in sales research: Perceived trust in business-tobusiness sales, a new measure. Journal of Personal_Selling \& Sales Management, 19(3), 61-71.

Connelly, B., Crook, T., Combs, J., Ketchen, D. Jr, \& Aguinis, H. (2018). Competence_and integrity-based trust in interorganizational relationships: Which matters more? Journal of Management, 44(3), 919-945. https://doi.org/10.1080/08853134.1999.10754182

Dionne, G. (2013). The empirical measure of information problems with emphasis on insurance fraud and dynamic data. In G. Dionne: Handbook of nsurance (pp.423-448). New York, NY: Springer.

Dumez,_H., \& Jeunemaître, A. (2000). Understanding and regulating the market at a time of globalization: The case of the cement industry. London, UK: Palgrave Macmillan. 
Efing, A. C., \& Desiderio, L. G. M. (2019). A responsabilidade do segurador no seguro garantia de término de obras. Revista de Direito CivilContemporâneo, 18(6), 141-168. Retrievedfrom https://dialnet.unirioja.es/servlet/articulo?codigo $=7611036$

Engel, A., Ganuza, J., Hauk, E., \& Wambach, A. (2006). Managing risky bids. In N. Dimitri, G. Piga., \& G. Spagnolo (Eds.). Handbook of Procurement (pp.322-344). Cambridge, UK: Cambridge University Press.

Esplugues, C., \& Marquis, L. (2015). New developments in civil and commercial mediation. Cham: Springer.

Estache, A., \& Martimort, D. (1999). Politics, transaction costs, and the design of regulatory institutions [World Bank Discussion Paper, 2073]. https://doi.org/10.1596/18139450-2073

Estache, A., Serebrisky, T., \& Wren-Lewis, L. (2015). Financing infrastructure in developing countries. Oxford Review of Economic Policy, 31(3-4), 279-304. Retrieved from https://doi.org/10.1093/oxrep/grv037

Flyvbjerg, B., Garbuio, M., \& Lovallo, D. (2009). Delusion and deception in large infrastructure projects: Two models for_explaining and preventing executive disaster. California Management Review, 51(2), 170-194. https://doi.org/10.2307/41166485

Galiza, F. (2015). Uma análise comparativa do seguro garantia de obras públicas. Estudos sobreSeguros, (29),13. Retrieved from https://www.ens.edu.br/arquivos/estudos ed29 fgaliza.pdf

Gentot, M. (1991). Les autorités administratives indépendantes. Paris, FR: Montchrestien.

Giuffrida, L., \& Rovigatti, G. (2019). Supplier selection and contract enforcement: evidence on performance bonding [Discussion Paper 18-045.] Mannheim, GER: Centre for European Economic Research.

Gondim, M. F. Filho, Rosário, J. O. R., \& Freire, L. (2018). Fiscalização do TCU e as garantias constitucionais do processo. Revista Digital Constituiçâo e Garantia de Direitos, 11(2), 155-174. Retrieved from https://periodicos.ufrn. br/constituicaoegarantiadedireitos/article/view/16167

Graham, B., Johnston, N., \& Kingsley, A. (2018). Even constrained government stake: The domestic politics of transfer and expropriation risks. Journal of Conflict Resolution, 62(8), 1784-1813. https://doi.org/10.1177/0022002717701181

Guasch, J.L. (2004). Granting and renegotiating infrastructure concessions: Doing it right. Washington, DC: World Bank.

Guasch, J. L., Laffont, J. J., \& Straub, S. (2008). Renegotiation of concession contracts in Latin America: Evidence from the water and transport sectors. International Journal of Industrial Organization, 26(2), 421-442. https://doi.org/10.1016/j.ijindorg.2007.05.003

Guest, G., Namey, E. E., \& Mitchell, M. L. (2013). Qualitative research: Defining and designing. In Collecting Qualitative Data: A Field Manual for Applied Research (pp.1-40). Thousand Oaks, CA: Sage Publications.
Guimarães, F. (2016). O Direito Administrativo do medo:_A crise da ineficiência pelo controle. Seção Colunistas Direito do Estado. Retrieved from http://www.direitodoestado.com. br/colunistas/fernando-vernalha-guimaraes/o-direitoadministrativo-do-medo-a-crise-da-ineficiencia-pelocontrole

Haddad, M., \& Amaral, C. (2011). O regime jurídico do seguro garantia: Uma análise comparative com o contrato de fiança. In Mattos Filho, Veiga Filho, Marrey Jr, \& Quiroga Advogados (Org.), Construindo um Novo Brasil: Principais desafios do regime jurídico da infraestrutura (pp.69-83). São Paulo, SP: Impressão Régia.

Hansell, D. S. (1996). Introduction to insurance. London, UK: LLP Professional Publishing.

Hart, O., \& Moore, J. (2007). Incomplete contracts and ownership: Some new thoughts. American Economic Review, 97(2), 182-186. https://doi.org/10.1257/aer.97.2.182

Hau, A. (2011). Optimal brokerage commissions for fair insurance: A first order approach. The Geneva Risk and Insurance Review, 36(2), 189-201. https://doi.org/10.1057/grir.2010.11

Hoetker, G., \& Mellewigt, T. (2009). Choice and performance of governance mechanisms: Matching alliance governance to asset type. Strategic Management Journal, 30(10), 10251044. https://doi.org/10.1002/smj.775

Hoffmann, A. F., \& Girolamo, J. A. (2017). O seguro garantia em projetos de infraestrutura. In E. A. R. Contani, \& E. J. R. F. Savóia (Orgs.), Infraestrutura no Brasil: Regulação, Financiamento e Modelagem Contratual. São Paulo, SP: Atlas.

Jensen, M. C., \& Meckling, W. H. (1976). Theory of the firm: Managerial behavior, agency costs and ownership structure. Journal of Financial Economics, 3(4), 305-360. https://doi.org/10.1016/0304-405X(76)90026-X

Kim, H., Cho, H., \& Ryu, D. (2019). Default risk characteristics of construction sure-ty bonds. The Journal of Fixed Income, 29(1), 77-87. https://doi.org/10.3905/jfi.2019.29.1.077

Kim, J., \& Mahoney, J. T. (2005). Property rights theory, transaction costs theory, and agency theory: an organizational economics approach to strategic management. Managerial and Decision Economics, 26(4), 223-242. https://doi.org/10.1002/mde.1218

Krummaker, S. (2016). Corporate demand for insurance: Empirical evidence from Germany [Working_Paper]. City University of London Institutional Repository.

Lakshmi, R.S., \& Santhi, P. (2015). Antecedents of customer perception of service quality of life insurance corporation of India. IUP Journal of Management Research, 14(3), 7081 .

Le Roy, S.F., \& Singell, D. (1987). Knight on Risk and Uncertainty. Journal of Political Economy, 95(2), 394-406. https://doi.org/10.1086/261461

Lei $\mathrm{n}^{\circ}$ 14.133, de $1^{\circ}$ de abril de 2021. (2021). Lei de Licitaçóes e Contratos Administrativos. Brasília, DF. Retrieved from http://www.planalto.gov.br/ccivil_03/_ato20192022/2021/lei/L14133.htm 
Maher, C., Hadfield, M., Hutchings, M., \& Eyto, A. (2018). Ensuring rigor in qualitative data analysis: A design research approach to coding combining NVivo with traditional material methods. International Journal of Qualitative Methods, 17(1), 1-13. https://doi.org/10.1177\%2F1609406918786362

Maia, F. (2013). A utilização do princípio venire contra factum proprium na isenção de responsabilidade da seguradora em sinistros de seguro garantia. Amazon's Research and Environmental Law, 1(1), 29-51. https://doi.org/10.14690/2317-8442.2013v1199

Mann, R. J. (1998). Verification institutions in financing transactions. Georgetown Law Journal, 87, 2225-2272. https://doi.org/10.2139/ssrn.142669

Marciano, A., Melcarne, A., \& Ramello, G. B. (2019). The economic importance of judi-cial institutions, their performance and the proper way to measure them. Journal of Institutional Economics, 15(1), 81-98. https://doi.org/10.1017/S1744137418000292

Marques, R. C., \& Berg, S. (2011). Risks, contracts, and privatesector participation in infrastructure. Journalof Construction Engineering and Management, 137(11), 925-932. https://doi.org/10.1061/(ASCE)CO.1943-7862.0000347

Marques, T. H., \& Turolla, F. A. (2017) Há um vazio institucional na mitigação de riscos no setor elétrico brasileiro? O caso do seguro-garantia. Anais do Seminário de Administração, São Paulo, SP, Brasil, 20.

Monteiro, L.D.S. (2016). As garantias contratuais no âmbito do financiamento de projetos. (Trabalho de Conclusão de Curso de especialização). Insper, São Paulo, SP, Brasil.

Navarro Sanfelix, G., \& Puig, F. (2018). New challenges in franchisor-franchisee relationship. An analysis from agency theory perspective. Cuadernos de Gestión. 18(1), 85-101. https://doi.org/10.5295/cdg.150610gn

Newell, S. J., Wu, B., Leingpibul, D., \& Jiang, Y. (2016). The importance of corporate and salesperson expertise and trust inbuildingloyal business-to-business relationshipsinChina. Journal of Personal Selling \& Sales Management, 36(2), 160173. https://doi.org/10.1080/08853134.2016.1190656

North, D.C. (1992). Transaction costs, institutions, and economic performance. San Francisco, CA: ICS Press. Retrieved from https://pdf.usaid.gov/pdf docs/PNABM255.pdf

Outreville, J.-F. (2012). The Geneva risk and insurance review 2011: A catalyst for new research ideas. The Geneva Papers on Risk and Insurance, 37(3), 594-602. https://doi.org/10.1057/gpp.2012.30

Panda, B., \& Leepsa, N. M. (2017). Agency theory: Review of theory and evidence on problems and perspectives. Indian Journal of Corporate Governance, 10(1), 74-95. https://doi.org/10.1177\%2F0974686217701467

Pereira, A. N. (2017). Seguro de garantia de obrigaçóes em contratos administrativos: A iniciativa privada e a alternativa pública (Dissertação de mestrado). Universidade Presbiteriana Mackenzie, São Paulo, SP, Brasil.
Pinheiro, A. C. (2014). A justiça e o custo Brasil. Revista USP, 101, 141-158. https://doi.org/10.11606/issn.2316-9036.v0i101p141-158

Poletto, G.A. (2003). O seguro garantia: Em busca de sua natureza jurídica. Rio de Janeiro, RJ: FUNENSEG.

Polido, W. (2015). Regulação do contrato de seguro e reflexos no resseguro: O Brasil abaixo do standard internacional. Anais do Fórum de Direito do Seguro "José Sollero Filho"-IBDS, 6 e Congresso Internacional de Direito do Seguro-Conselho da Justiça Federal e Superior Tribunal de Justiça, 1. São Paulo: Roncarati-IBDS.

Poveda, E. P. R. (2012). Seguro_garantia_como_instrumento de gestão para a mitigação de danos ambientais na mineração (Tese de doutorado). Universidade Estadual de Campinas, Campinas, SP, Brasil.

Pradhan, R.P., Arvin, M.B., Nair,M., \& Bennett,S. (2020).Unveiling the causal relationships among banking competition, stock and insurance market development, and economic growth in Europe. Structural Change and Economic Dynamics, 55, 74-87. https://doi.org/10.1016/j.strueco.2020.08.006

Reis, V. M. S. (2012). Ensaios sobre seleção adversa e risco moral no mercado de crédito (Dissertação de mestrado). Fundação Getulio Vargas, São Paulo, SP, Brasil.

Ribeiro, J. L. D., Machado, C. O., \& Tinoco, M. A. C. (2010). Determinantes da satisfação e atributos da qualidade em serviços bancários. Gestão \& Produção, 17(4), 775-790. https://doi.org/10.1590/S0104-530X2010000400011

Russell, J. S. (2000). Surety bonds for construction contracts. Reston: ASCE.

Schnaider, P. S. B., Ménard, C., \& Saes, M. S. M. (2018). Heterogeneity of plural forms: A revised transaction cost approach. Managerial and Decision Economics, 39(6), 652663. https://doi.org/10.1002/mde.2935

Schubert, L. M. (2000). Why obligees buy bonds. In E. G. Gallagher (Ed.), The law of Suretyship. Chicago, IL: ABA.

Shahab,S., Clinch,J., \&O’Neill,E.(2018).Accountingfortransaction costs in planning policy evaluation. Land Use Policy, 70, 263272. https://doi.org/10.1016/j.landusepol.2017.09.028

Silva, E. B. Filho da (2006). A teoria da firma e a abordagem dos custos de transação: elementos para uma crítica institucionalista. Pesquisa \& Debate. Revista do Programa de Estudos Pós-Graduados em Economia Política, 17(2), 259-277. Retrieved from https://revistas.pucsp.br/index. php/rpe/article/view/11819/8544

Smit, H., Pennings, E., \& Van Bekkum, S. (2017). Real options and institutions. Journal of International Business Studies, 48(5), 620-644. https://doi.org/10.1057/s41267-016-0055-7

Smith, C. W., \& Warner, J. B. (1979). On financial contracting: An analysis of bond covenants. Journal of Financial Economics, 7(2), 117-161. https://doi.org/10.1016/0304-405X(79)90011-4 
Somavilla, J. \& Pereira, A. T. (2018). Possibilidade de utilização da performance bond nos contratos administrativos de obras públicas, à luz da Lei no 8.666/93. Anuário Pesquisa e Extensão Unoesc São Miguel do Oeste, 3, e19788-e19788. Retrieved from https://portalperiodicos.unoesc.edu.br/ apeusmo/article/view/19788

Sun, R.T., Garimella, A., Han, W., Chang, H. L., \& Shaw, M. J. (2020). Transformation of the transaction cost and the agency cost in an organization and the applicability of blockchain: A case study of peer-topeer insurance. Frontiers in Blockchain, 3(24),1-16. https://doi.org/10.3389/fbloc.2020.00024

Superintendência de Seguros Privados (2020a). Registro de operaçóes de seguro garantia passa a ser obrigatório a partir de hoje. Noticias Susep. Retrieved from http://novosite. susep.gov.br/noticias/registro-de-operacoes-de-segurogarantia-passa-a-ser-obrigatorio-a-partir-de-hoje/

Superintendência de Seguros Privados (2020b). Senado aprova projeto de lei de licitaçóes e amplia seguro garantia para obras públicas. Notícias Susep. Retrieved from http:// novosite.susep.gov.br/noticias/senado-aprova-projetode-lei-de-licitacoes-e-amplia-seguro-garantia-para-obraspublicas/

Surahyo, A. (2018). Construction risk analysis and management. In Understanding Construction Contracts (pp.97-106). Cham: Springer

Terra, A. D. M. V., \& Salgado, B. (2020). O risco no seguro garantia e o inadimplemento anterior ao termo. Revista Jurídica Eletrônica da UFPI, 7(1), 18-39. Retrieved from https://revistas.ufpi.br/index.php/raj/article/view/11715

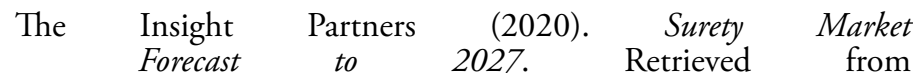
https://www.theinsightpartners.com/reports/surety-market
Tzirulnik, E. (2015). Seguro de riscos de engenharia: Instrumento do desenvolvimento (Tese), Universidade de São Paulo, São Paulo, SP, Brasil.

Wambach, A., \& Engel, A. R. (2011). Surety bonds with fair and unfair pricing. The Geneva Risk and Insurance Review, 36(1), 36-50. https://doi.org/10.1057/grir.2010.8

Williamson, O. E. (2002). The theory of the firm as governance structure: From choice to contract. Journal of Economic Perspectives, 16(3), 171-195. Retrieved from https://www.jstor.org/stable/3216956

Williamson. O. E. (2012). As instituiçôes econômicas do capitalismo: Firmas, mercados e relaçóes contratuais. São Paulo, SP: Pezco Editora.

Yao, J., Zhang, Z., \& Brett, J. (2017). Understanding trust development in negotiations: An interdependent approach. Journal of Organizational Behavior, 38(5), 712729. https://doi.org/10.1002/job.2160

Yescombe, E., \& Farquharson, E. (2018). Public-Private Partnerships for infrastructure: Principles of policy and finance. Oxford: Butterworth-Heinemann.

Yeung,L., Silva,A.L., \& Carvalho, C.E.(2014).Ainsegurançajurídica o devedor: Pela ampliação do debate sobre seleção adversa e custo do crédito no Brasil. Análise Econômica, 32(61), 63-80. https://doi.org/10.22456/2176-5456.33989

Zweifel, P., \& Eisen, R. (2012). Insurance markets and asymmetric information. In Insurance Economics (pp.265-313). Berlin, GER: Springer. 


\section{Authorship}

\section{Tulio Henrique Moreira Marques*}

Escola Superior de Propaganda e Marketing, Programa de Pósgraduação em Administração

Rua Dr. Alvaro Alvim, n. 123, Vila Mariana, 04018-010, São Paulo, SP, Brazil

E-mail: tulio.marqs@gmail.com

(1) https://orcid.org/0000-0003-2656-6072

\section{Mario Henrique Ogasavara}

Escola Superior de Propaganda e Marketing, Programa de Doutorado e Mestrado em Gestão Internacional

Rua Dr. Alvaro Alvim, n. 123, Vila Mariana, 04018-010, Sáo Paulo, SP, Brazil

E-mail: mario.ogasavara@espm.br

(1) https://orcid.org/0000-0001-8988-5762

\section{Frederico Araujo Turolla}

Escola Superior de Propaganda e Marketing, Programa de Doutorado e Mestrado em Gestão Internacional

Rua Dr. Alvaro Alvim, n. 123, Vila Mariana, 04018-010, São

Paulo, SP, Brazil

E-mail: fredturolla2@gmail.com

(1) https://orcid.org/0000-0002-7313-6705

* Corresponding Author

\section{Funding}

The authors reported that there is no financial support for the research in this article.

\section{Conflict of Interests}

The authors have stated that there is no conflict of interest.

\section{Plagiarism Check}

The RAC maintains the practice of submitting all documents approved for publication to the plagiarism check, using specific tools, e.g.: iThenticate.

\section{Authors' Contributions}

$1^{\text {st }}$ author: conceptualization (lead); data curation (equal); formal analysis (equal); investigation (equal); methodology (equal); project administration (equal); resources (lead); software (lead); supervision (equal); validation (supporting); visualization (supporting); writing-original draft (equal); writing-review \& editing (supporting).

$2^{\text {nd }}$ author: conceptualization (supporting); data curation (equal); formal analysis (equal); investigation (equal); methodology (equal); project administration (equal); resources (supporting); software (supporting); supervision (equal); validation (lead); visualization (lead); writing-original draft (equal); writing-review $\&$ editing (lead).

$3^{\text {rd }}$ author: conceptualization (supporting); data curation (equal); formal analysis (equal); investigation (equal); methodology (equal); project administration (equal); resources (supporting); software (supporting); supervision (equal); validation (supporting); visualization (lead); writing-original draft (equal); writing-review \& editing (lead).

\section{Copyrights}

RAC owns the copyright to this content.

\section{Peer Review Method}

This content was evaluated using the double-blind peer review process. The disclosure of the reviewers' information on the first page, as well as the Peer Review Report, is made only after concluding the evaluation process, and with the voluntary consent of the respective reviewers and authors

\section{Data Availability}

RAC encourages data sharing but, in compliance with ethical principles, it does not demand the disclosure of any means of identifying research subjects, preserving the privacy of research subjects. The practice of open data is to enable the reproducibility of results, and to ensure the unrestricted transparency of the results of the published research, without requiring the identity of research subjects. 